\title{
The Procedure for the Creation of New Regional States under the FDRE Constitution: Some Overlooked Issues
}

Tessema Simachew Belay* and Habtamu Simachew Belay **

\begin{abstract}
The Ethiopian Federation which was created by the 1995 Federal Democratic Republic of Ethiopia (FDRE) Constitution had nine member states and one city administration. Apart from the creation of Dire Dawa as a city administration, no new state has been introduced in the Ethiopian federation since the adoption of the Constitution. However, several ethnic-based Zonal administrations in the country's Southern Nations, Nationalities and Peoples (SNNP) region are now demanding to form their own regional states. Apparently, the demands are justified under Article 47(2) of the 1995 Ethiopian constitution which follows a purely ethnic-centered approach by giving "each nation, nationality and people" living in the nine States of the federation "the right to establish their own States at any time." However, since this right has so far never been exercised in practice, the new demands are creating anxiety in some quarters and drawing a growing attention to the constitutional procedure for the creation of new states. This article aims to critically examine the relevant constitutional provisions dealing with the issue of creation of new states. Drawing insights from some other federations, we argue that the ethnic-centered approach taken under the FDRE Constitution for the creation of new states overlooks several important issues such as economic viability, administrative efficiency, equity, sustainable peace, and resilience of the federal system.
\end{abstract}

\section{Key terms:}

Creation of new states $\cdot$ Ethnic federalism $\cdot$ Self-determination $\cdot$ Nation,

Nationality or People (NNP)

DOI http://dx.doi.org/10.4314/mlr.v13i1.4

This article is licensed under a Creative Commons Attribution-NonCommercialNoDerivs (CC BY-NC-ND)

\footnotetext{
* Tessema Simachew Belay (LL.B., LL.M., Ph.D), Assistant Professor, Bahir Dar University, School of Law. Email: tessim43@gmail.com

** Habtamu Simachew Belay (LL.B., LL.M., LL.M., Ph.D.), Assistant Professor, Wollo University, School of Law. Email: habtesim@yahoo.com

We are grateful to the anonymous reviewers for their insightful and valuable comments on the draft article. All errors remain ours.
} 


\section{Introduction}

Federations have constituent units with substantial legislative, executive and judicial power. The numbers of these component units, however, vary from one federation to the other and are not necessarily proportional to the landmass or the population size of the country. For example, India, a Federation of more than 1 billion people, has 29 states and seven union territories ${ }^{1}$, while Switzerland, a country of about 8 million people, has 26 cantons. The United States has 50 states (plus two federacies), three local home-rule territories and three unincorporated territories; Australia has six states (plus four administered territories, three territories and one capital territory; Canada has ten provinces (plus two territories); Malaysia has 13 states, and Nigeria has 36 states. ${ }^{2}$

Some federations have shown relative stability in the number of their constituent units. For example, apart from the creation of Jura as a separate canton in 1979, the number of cantons in Switzerland remained stable since $1848 .{ }^{3}$ By contrast, the territorial boundaries of other federations have gone through frequent changes. For example, a series of state creation exercises in Nigeria and India brought about numerous new states. Beginning with three regions prior to the Nigerian Civil War (1966-70), the Nigerian Federation grew to 36 states by $1996 .{ }^{4}$ India, on its part, which was reorganized in 1956 into 13 states $^{5}$ has now 29 states. $^{6}$

The Ethiopian Federation which was created by its 1995 constitution had nine member states ${ }^{7}$ and one city administration. ${ }^{8}$ Apart from the creation of

\section{Frequently used acronyms:}

FDRE Federal Democratic Republic of Ethiopia

NNP Nations, Nationalities and Peoples

SNNP Southern Nations, Nationalities and Peoples

1 <http://www.india.gov.in/india-glance/profile> [Last accessed on July 19, 2019].

2 See R.A. Akindele (2001), 'Nigeria in the Global Market of Experiments in Federalism,' in J.I. Elaigwu and R.A. Akindele (eds.) Foundations of Nigerian Federalism. 1960-1995, National Council on Intergovernmental Relations, Abuja, at p. 13.

${ }^{3}$ See T.K. Reuter (2016), "The Right to Self-Determination of Ethnic Groups: The Canton of Jura in Switzerland", International Journal on Minority and Group Rights, Vol. 23 No. 2, p. 260.

${ }^{4}$ See Adewale Stephen Adeniyi (2004), "Quest for State's Creation in Nigeria: an Harbinger of Development or Underdevelopment?", Journal of Culture, Society and Development, Vol.4, at p. 68.

${ }^{5}$ See The States Reorganisation Act, 1956, Section 12.

${ }^{6}$ Supra note 1 .

${ }^{7}$ See the Constitution of the Federal Democratic Republic of Ethiopia, 1995, Federal Negarit Gazeta, Proc. No. 1/1995, No.1, 1st year 1995 (Hereinafter: FDRE Constitution), Article 47(1). 
Dire Dawa as a city administration which is accountable to the Federal Government by a Federal proclamation ${ }^{9}$, in the more than two decades of the Constitution's existence, no new regional state has been introduced in the Ethiopian federation. This might be surprising considering the Constitution's clear declaration that each nation, nationality and people has the right to form its own state. ${ }^{10}$

However, it appears that the relative stability the federation has witnessed so far in terms of the number of its member states is likely to change soon. Several ethnic-based Zonal administrations in the Southern Nations, Nationalities and Peoples' Region (SNNPR) are now demanding to form their own regional states. ${ }^{11}$ Against this background, this article aims to critically examine the constitutional procedure for the creation of new states in Ethiopia.

Before delving into the details of the constitutional procedure for the creation of new states, the first section of this article deals with the FDRE Constitution's general orientation that conceives Ethiopia as a consent-based marriage of its diverse ethnic groups. It is argued that this ethnic-centered orientation is what shapes and informs the main features of the Ethiopian federalism, including the procedure for state creation. The second section of the article presents and analyzes the constitutional procedure for the creation of new states as enshrined in Article 47 of the Constitution as one of the aspects of the ethnic-centered

${ }^{8}$ According to Article 49(2) of the FDRE Constitution "[r]esidents of Addis Ababa shall have a full measure of self-government." Sub-article 3 of the same provision further states that "[t]he Administration of Addis Ababa shall be responsible to the Federal Government."

${ }^{9}$ The recognition of Dire Dawa as a city accountable to the Federal Government was a temporary arrangement until such a time that the then claims of the Somalia and Oromia regions would finally be resolved.See the Preamble of Dire Dawa Administration Charter Proclamation, 2004, Federal Negarit Gazeta, Proc. No. 416/2004, 10 ${ }^{\text {th }}$ year, No. 60, 2004. Since the FDRE Constitution did not as such talk about any city accountable to the Federal government other than Addis Ababa, some writers rightly note that the DireDawa situation can be characterized as an instance of "constitutional amendment by legislation." See Nigussie Afesha (2016), "The Practice of Informal Changes to the Ethiopian Constitution in the Course of Application", Mizan Law Review, Vol. 10, No. 2, at p. 387.

${ }^{10}$ See Article 47(2) of FDRE Constitution.

11 "Demands for Regional Status Rock Ethiopia's South Region", 7Dnews, https://7dnews.com/news/deamds-forregional-status-rock-ethiopia-s-south-region[last accessed on March 27, 2019]; Brook Abdu, Sidama's Quest for Statehood, The Reporter, 10 November 2018, https://www.thereporterethiopia.com/article/sidamas-queststatehood[last accessed on March 27, 2019]. Sidama's quest for regional statehood is in particular at advanced stage as a date for referendum is already fixed for November 13 , 2019. https://www.africanews.com/2019/08/29/ethiopia-slates-november-13-for-sidamaautonomy-referendum//. 
nature of the Ethiopian Federalism. This ethnic-centered orientation is manifested in the content of the procedure for creation of constituent units that solely gives the power to the ethnic group that raises the question.

In Section 3, the ethnic-centered approach in Ethiopia's constitution is contrasted with the procedures adopted for the creation of new constituent units in some other federations. To this end, the section presents an overview of the constitutional procedure for creation of new States in several federations, and further includes a closer look into the history and procedures of state creation in two selected federations, Nigeria and India. These countries are chosen because both countries are ethnically diverse, and agitations for the creation of new states in both countries have over the years led to the introduction of new federal units. Based on the analysis of the procedure for the creation of new states in the FDRE constitution and the insights drawn from the examination of the experiences of other countries, some important issues that are overlooked in the Ethiopian constitutional arrangement are discussed in Section 4.

\section{The 1995 FDRE Constitution: Reconceiving Ethiopia as a Marriage of its Ethnic Groups}

Ethiopia is one of the oldest States in Africa with a unique history. ${ }^{12}$ At the beginning of the 20th century, it was one of the few countries in Africa that was not under colonial rule. This image of an old and proud Ethiopia ${ }^{13}$ is however far from being uncontroversial. Depending on their historiographic paradigm, different people associate different, sometimes conflicting, images with Ethiopia. ${ }^{14}$ The tension between these competing paradigms is the driving force in some of the constitutional changes and the resulting transformations in the political organization the country has gone through in the $20^{\text {th }}$ century.

Although historical Ethiopia can actually be described as a de facto federal state, ${ }^{15}$ three of the four modern written constitutions of Ethiopia were unitarist

${ }^{12}$ Ethiopia is widely believed to be the birth place of mankind, and as such, there is a long history of human habitation in what we now call Ethiopia. See Harold Marcus (1994), A History of Ethiopia, Berkeley, University of California Press, pp.1-17.

${ }^{13}$ Though Ethiopia existed as a state for many centuries, it did exist in different shapes and sizes, sometimes expanding while shrinking at other times. See Getachew Assefa (2012), Ethiopian Constitutional Law with comparative Notes and Materials: A Textbook, Addis Ababa University, Addis Ababa, at p. 253.

${ }^{14}$ Teshale Tibebu identifies different sometimes conflicting images associated with Ethiopia including "Christian Ethiopia", "Semetic Ethiopia", "the Authentic African Ethiopia", "the black colonial power Ethiopia" etc. See Teshale Tibebu (1996), "Ethiopia: The "Anomaly" and "Paradox" of Africa," Journal of Black Studies, Vol. 26, No. 4, at p. 427.

${ }^{15}$ Assefa Feseha (2006), Federalism and the Accommodation of Diversity in Ethiopia: a Comparative Study, Wolf Legal Publishers, the Netherlands, 2006, at p. 16. 
in their orientation. Ethiopia's first written constitution was introduced 1931 by Emperor Haile Selassie I, and it gave a modern image to the old monarchical system. ${ }^{16}$ The 1931 Constitution proclaimed that "in the Ethiopian Empire, supreme power rested in the hands of the Emperor." ${ }^{\prime 17}$ It was practically used by the Emperor as a means of facilitating the centralization of power in his hands. ${ }^{18}$

The 1931 Constitution was revised in 1955. The revision was largely necessitated by the Federation of Eritrea with Ethiopia in 1952. ${ }^{19}$ The fact that Eritrea possessed a Constitution far more modern than Ethiopia's pushed the Emperor, who was very sensitive to international opinion, to give a blessing for the revision of the 1931 Constitution. ${ }^{20}$ Despite the creation of a bicameral parliament and the introduction of some progressive changes ${ }^{21}$, in the 1955 Revised Constitution, the sovereignty of the Empire was still vested in the Emperor and "the supreme authority over all the affairs of the Empire" was "exercised by Him." 22 Due to its centralizing mission and apparent incompatibility with the rather democratic 1952 Constitution of Eritrea ${ }^{23}$, the Revised constitution appears to have contributed for the subsequent dissolution of the Federation in 1962.

The unitary system of government continued after the revolution of 1974 that replaced the monarchical government. The military junta ruled Ethiopia as a provisional government for more than ten years. The 1987 Constitution of Ethiopia, which was adopted four years before the fall of Derg in 1991, adopted a unitary form of government. ${ }^{24}$ Article 2(1) of the 1987 PDRE (Peoples' Democratic Republic of Ethiopia) Constitution declared: "The Peoples' Democratic Republic of Ethiopia is a unitary state in which all nationalities live

16 See John Markakis and Asmelash Beyene (1967), "Representative Institutions in Ethiopia," Journal of Modern African Studies, Vol. 5, No.2, pp. 193-217 partly reproduced in Getachew Assefa, supra note 13, at p. 261.

${ }^{17}$ See Article 6 of the 1931 Constitution.

${ }^{18}$ See John Markakis and Asmelash Beyene,supra note 16, at p. 263.

${ }^{19}$ See Assefa Fisseha, supra note 15, at p.38.

${ }^{20}$ See Markakis and Asmelash, supra note 18.

${ }^{21}$ For a very positive view regarding the contribution and the qualities of the 1955 Revised Constitution, see in general Minassie Haile (2005), "Comparing Human Rights in Two Ethiopian Constitutions: The Emperor's and the "Republic's"-Cucullus Non Facit Monachum", Cardozo J. Int'L and Comparative Law, Vol. 13, pp. 1-59.

${ }^{22}$ See Article 26 of the Revised Constitution of 1955. For an overview on the Revised Constitution, See William H. Lewis (1956). "Documents: Ethiopia's Revised Constitution”, Middle East Journal, Vol. 10, No. 2, pp. 194-199.

${ }^{23}$ See Assefa Fisseha, supra note 15, at p. 44.

${ }^{24}$ See the Constitution of the People's Democratic Republic of Ethiopia, Proclamation No. 1 of 1987, Negarit Gazetta, Vol. 47, No. 1, Addis Ababa, 12 September 1987. [hereinafter: PDRE Constitution] 
in equality." Despite adopting a unitary form of government, the Constitution noted that the state will be comprised of "administrative and autonomous regions" 25 and that it "shall ensure equality of all nationalities"26 and "regional autonomy". ${ }^{27}$ However, the power "to establish administrative and autonomous regions and determine their boundary, level of hierarchy and accountability" was given to the National Shengo, the highest political organ in the PDRE. ${ }^{28}$

Due to its socialist orientation, the Constitution defined the People's Democratic Republic of Ethiopia as "a State of the working people founded on the alliance of workers and peasants and the participation of the intelligentsia, the revolutionary army, artisans and other democratic sections of society." 29 Although the equality of all nations is repeatedly affirmed in the PDRE Constitution, the various ethnic groups of Ethiopia were not as such conceived as the original contractors of the constitutional arrangement.

The overthrow of the Derg regime in 1991, marked an end of a unitarist era in Ethiopian political history and brought what is usually called the "nationality question" to the forefront. The change, which coincided with the disintegration of Yugoslavia and the USSR brought the Ethiopian Peoples' Revolutionary Front (EPRDF) to power. The unitarist bureaucratic structure including the national army was dismantled and replaced by EPRDF leadership; and a new national army composed of the former rebel fighters was created. The years prior to the adoption of the FDRE Constitution in 1995 were dominated by nationalist movements. ${ }^{30}$

\footnotetext{
${ }^{25}$ Ibid, Article 59.

${ }^{26}$ Ibid, Article 2(2).

${ }^{27}$ Ibid, Article 2(4).

${ }^{28}$ Ibid, Article 63(2)(a).

${ }^{29}$ Ibid, Article 1(1).

${ }^{30}$ Writing in 1993 Andreas Eshete captured the situation at the time in the following words: "The answer to the question of whether Ethiopian citizens will effectively exercise their rights has complicated another challenge that the country presently faces. The struggle against authoritarian power has prompted the various nationalist movements. The most powerful organizations are animated by ardent nationalist sentiments. All the groups who participated in the July 1991 conference endorsed the collective rights in the charter, which reserves large powers to cultural communities. Since then, the transitional government issued a proclamation on the establishment of regions and regional governments. A striking feature of the statute is that it defines regions almost exclusively by reference to ethnic identity. If the statute is upheld by the new constitution, Ethiopia will become a federation of self-governing ethnic communities" Andreas Eshete (1993), "Implementing Human Rights and a Democratic Constitution in Ethiopia", Issue: A Journal of Opinion, Vol. 21, No. 1/2, at p. 10.
} 
As a result, just like in the Transitional Period ${ }^{31}$, the 1995 FDRE Constitution continued to define the regional states by reference to ethnic identity. From a conceptual standpoint, the 1995 constitution practically reorganized the Ethiopian state. The reorganization occurred in the form of a total shift from the unitarist tendencies of the previous regimes. In this regard, Andreas Eshete noted that "although the Ethiopian Federalism was born in the wake of a longstanding unitary state, the constitutional principles governing federalism exemplifies features of coming-together federalism."32 Andreas did not however consider the self-image of the political order that the FDRE Constitution created as a coming-together federalism as a mere constitutional fiction. That is because, on the one hand, with either defeat or exile of multinational political organizations, the main political actors in the Transitional Period were representatives of ethnic groups. ${ }^{33}$ Besides, in Tigray, for example, the struggle for self-rule had already succeeded while Derg was still in power. ${ }^{34}$

Despite observing aspects of 'coming together' federalism in the FDRE Constitution, scholars also note its 'holding together' features. ${ }^{35}$ Assefa Fiseha, for example, argues that since the federation has some 'holding together' aspects, considering it as "a federation built from the nationalities, will be an exaggeration" "I6 support of this position he inter alia noted: "[a]lthough some parts of the country experienced a de facto autonomy in the pre-1991 period, many of the constituent states that now form the federation had no such experience previously." 37 And he further observed, "the federation is incomparable to the states and cantons, for instance, of the United States and Switzerland." 38

It is true that the Ethiopian federation was not, in fact, a coming together federation created through the negotiation of ethnic entities which have previously existed independently. It might of course be very puzzling to think how a hitherto unitarist State like Ethiopia could be reconceived as a coming together federation. It still cannot be ignored that under the FDRE Constitution, the "nations, nationalities or peoples" of Ethiopia are, at least in principle,

\footnotetext{
${ }^{31}$ Though the Transitional Charter (1991) did not delimit the boundaries of the selfgoverning regions that was done by Proclamation No. 7/1992.

${ }^{32}$ See Andreas Eshete (2003), "Ethnic federalism: new frontiers in Ethiopian politics", the first national conference on Federalism, Conflict and Peace Building, Ministry of Federal Affairs and German Technical Cooperation, Addis Ababa, at pp. 160-161.

${ }^{33}$ Ibid, at p. 161.

${ }^{34}$ Ibid.

${ }^{35}$ See Assefa Fiseha, supra note 15, at p. 213.

${ }^{36}$ Ibid, at p. 214.

${ }^{37}$ Ibid.

${ }^{38}$ Ibid.
} 
endowed with powers that are not available to states in a truly coming together federations such as the USA. For example, as it will be observed below, members of the US federation do not have a unilateral right to secede while every nation, nationality or people (NNP) in Ethiopia has a right to form its own independent state. This, in our view, is the result of the redefinition of Ethiopia as a consensual marriage of its ethnic groups (under the FDRE Constitution).

The essence of this redefinition lies in an approach that considers the various ethnic groups living in Ethiopia as the original negotiators and the founding members of the Federation. This is manifested in the FDRE constitution starting from the Preamble. The Preamble starts with the words, "We the Nations, Nationalities and Peoples of Ethiopia Strongly committed, in full and free exercise of our right to self-determination ...", indicating the fact that the Constitution is a covenant between Ethiopia's ethnic groups.

This sentiment is reflected in Article $8(1)$ of the Constitution which proclaims that "[a]ll sovereign power resides in the Nations, Nationalities and Peoples of Ethiopia." Article 8(2) further describes the Constitution as "expression of their sovereignty." According to the FDRE Constitution, when the "nations, nationalities and peoples" of Ethiopia create the Federation, they reserved to themselves the unconditional right to leave the Union. As such, unlike the American Federation which was historically a coming together federalism, and yet is considered as a perpetual union ${ }^{39}$, the Ethiopian Constitution which actually transformed a unitary State into a coming together type of federalism, was not conceived as a perpetual union.

Hence, the famous Article 39 of the Constitution grants all nations, nationalities and peoples (NNP) of Ethiopia an unconditional right to selfdetermination up to secession. ${ }^{40}$ This provision is arguably the most controversial provision of the Constitution. ${ }^{41}$ The historical source of such a

${ }^{39}$ The US Constitution does not explicitly deal with the issue of secession. However, the U.S Supreme Court once held that the federation is in principle considered to be a perpetual union. For more on the notion of perpetual union, see, in general, Kenneth M. Stamp (1978), "The Concept of a Perpetual Union", Journal of American History, Vol. 65 , No. 1, pp. 5-33.

${ }^{40}$ For a discussion on Article 39, see in general Ahmednasir M. Abdullahi (1998), "Article 39 of the Ethiopian Constitution on Secession and Self-Determination: A Panacea to the Nationality Question in Africa?", Law and Politics in Africa, Asia and Latin America, Vol. 31, No. 4, pp. 440-455.

${ }^{41}$ More generally, the issue of ethnic federalism in Ethiopia is very contested. See John Young (1996), "Ethnicity and Power in Ethiopia", Review of African Political Economy, No. 70, at p. 537. The main argument against the ethnic federalism is that it might lead to further ethnic fragmentation and conflicts which in turn may bring about the total collapse of the state. See, for example, Minassie Haile (1996), "The New Ethiopian Constitution: 
provision can be traced back to the writings of Lenin on the issue that were very popular in the Ethiopian students' Marxist-Leninist movement in the 1960s, ${ }^{42}$ In 1969, Wallelign Mekonnen challenged the characterization of Ethiopia as a "nation."

[S]ociologically speaking at this stage Ethiopia is not really one nation. It is made up of a dozen nationalities with their own languages, ways of dressing, history, social organization and territorial entity. And what else is a nation? It is not made of a people with a particular tongue, particular ways of dressing, particular history, particular social and economic organization? Then may I conclude that in Ethiopia there is the Oromo Nation, the Tigrai Nation, the Amhara Nation, the Gurage Nation, the Sidama Nation, the Wellamo [Wolayta] Nation, the Adere [Harari] Nation, and however much you may not like it the Somali Nation. ${ }^{43}$

Article 39 of the FDRE Constitution is, therefore, the ultimate manifestation of the reconceptualization of Ethiopia as a mere marriage of its ethnic groups. It is this expansive protection to the right to self-determination of the ethnic groups living within the borders of Ethiopia that also sets the tone for the constitutional procedure adopted for the creation of new regional states in the Ethiopian federation.

\section{Member States of the Federation and the Procedure for the Creation of New States: An ethnic-centered Approach}

The image the FDRE Constitution portrays as a coming together federalism negotiated and created by the ethnic groups of Ethiopia is only partly reflected in the way the original constituent units of the federation were organized. In a country with more than 80 ethnic groups, the FDRE Constitution created only nine regional states, thereby making most of the regions multi-ethnic. However, even within the framework of the original organization, the Constitution is unequivocal in affirming the ethnic based nature of the federation. The mismatch between the conceptual starting point of the FDRE Constitution and the actual 9-states organization of the federation is reconciled by giving each

Its Impact upon Unity, Human Rights and Development", Suffolk Transnational Law Review, Vol. 20, No. 1, pp. 1-84.

${ }^{42}$ See Lenin (1914), “The Right of Nations to Self-determination” April-June, 1914, Reproduced in Lenin (1977), Collected Works, Vol. 20, Progress Publishers, Moscow, pp. $395 \mathrm{ff}$.

${ }^{43}$ See Wallelign Mekonnen (1969), "On the Question of Nationalities in Ethiopia”, HSIU, Arts IV, Nov. 17, 1969. 
ethnic group the right to create its own regional state in a procedure that gives the ultimate say to the group which raised the question.

\subsection{The original constituent units of the federation}

According to Article 46 of the FDRE Constitution, "the Federal Democratic Republic shall comprise of States," and their delimitation shall be "on the basis of the settlement patterns, language, identity, and consent of the people." The relative weight given to the various criteria in the creation of regional states is not clear. It is not also clear to what extent the criteria were applied by the drafters when they created the original nine members of the Federation listed under Article 47(1) of the FDRE Constitution.

Considering the central place the nations, nationalities and peoples are expected to play in the constitutional arrangement, holding "all sovereign power" and having "an unconditional right to self-determination including the right to secession," one would expect their consent to play a huge role in the creation of States. In reality, however, consent of the people concerned did not appear to have played a big role in the creation of the original member States of the Federation. Apparently, there were no referendums conducted when the original delimitation was done.

Article 47(1) recognizes nine regional states as the members of the Federal Democratic Republic of Ethiopia. These are: the State of Tigray, the State of Afar, the State of Amhara, the State of Oromia, the State of Somalia, the State Benshangul/Gumuz, the State of the Southern, Nations, Nationalities and Peoples, the State of the Gambela Peoples, and the State of Harari People.

Few observations can be made regarding the list of States recognized by the Constitution. First, in terms of terminological choice, while the official Amharic version $^{44}$ refers to the states as "kilil", which could have been translated to "region", the English version employs the term "State" using the capital "S". In referring to the regional states as "the State of Tigray", "State of Oromia" etc, the Constitution appears to follow the pattern of the official name of some sovereign countries such as "State of Eritrea", "State of Israel" and "State of Kuwait".

This problematic terminological choice of the English version becomes even more confusing when it comes to the way the Constitution referred to one of the regions. Somali region is referred to as "the State of Somalia." Considering there is a neighboring State with the name Somalia, this nomenclature is clearly confusing. Probably recognizing the problematic nature of the constitutional nomenclatures, regional states in Ethiopia officially refer to themselves as

\footnotetext{
${ }^{44}$ According to Article 106 of the FDRE Constitution, it is the Amharic version that has the final legal authority.
} 
"national regional states". ${ }^{45}$ What the Constitution calls "State of Somalia" is also referred to as "Somali regional State" 46 , apparently with a view to distinguish it from Somalia.

The way the Constitution chose to name most of the regions indicates its unequivocal emphasis on ethnicity in organizing the constituent units. Five of the nine regional states of the federation, namely, Tigray, Amhara, Oromia, Somali and Afar are named after the ethnic group which has the overwhelming majority in the respective regions. ${ }^{47}$ The emphasis on ethnicity is exhibited in the way the Harari region is named after the Harari ethnic group even though other two numerically superior ethnic groups reside in the region. ${ }^{48}$

Paradoxically though, more than 50 ethnic groups in southern Ethiopia were put in a single region called the Southern Nations, Nationalities, and Peoples. That was done by changing the regional arrangement that was in place in the Transitional Period that recognized five regions in the area, namely, Sidama, Wolaita, Omo, Kaffa, and Guraghe-Hadya-Kambata. ${ }^{49}$ Some of these ethnic groups such as Sidama have more population than some of the original member states of the Federation. It is therefore not clear what objective criteria were used to make the original delimitation. In this regard, Anderson noted that the original decisions concerning the boundaries of the constituent units in Ethiopia were essentially made by the ruling coalition, EPRDF, in a process that "had minimal openness" and "very limited public consultation". 50

\subsection{The right to create new regional states and its procedure}

There appears to be an apparent mismatch between the conceptual starting point of the FDRE Constitution that conceives each nation, nationality and people as the original negotiator and founding member of the federation and the actual 9states organization of the federation. This situation was probably inevitable as giving each ethnic group its own regional state is unnecessary and impractical. Nevertheless, the Constitution reconciled the apparent conflict by giving each

\footnotetext{
${ }^{45}$ See for example, Article 1 of the 2001 Revised Constitution of Amhara Regional State.

${ }^{46}$ See Article 1 of the Revised Constitution of the Somali Regional State, April 2002.

${ }^{47}$ See Jaap de Visser, Nico Steytler and Yonatan Feseha (2016), "The Role of Ethnicity in the Demarcation of Internal Boundaries in South Africa and Ethiopia", paper presented at the Annual Conference of the International Association of Centres for Federal Studies, Rome, Sept. 2012, at p. 3.

${ }^{48}$ Ibid.

${ }^{49}$ See Nigussie Afesha Aytaged (2016), "The Ethiopian Constitutional Promises to the Nation and Nationalities: The Myth and the operational reality", Bahir Dar University Journal of Law, Vol. 6, No. 2, at p. 241.

${ }^{50}$ See George Anderson (2014), Creation of Constituent Units in Federal Systems, Center for Constitutional Transitions at NYU Law, at p. 6.
} 
nation, nationality and people the right to create its own regional state. Article 47(2) unequivocally affirmed this right: "Nations, Nationalities and Peoples within the States enumerated in sub-Article 1 of this article have the right to establish, at any time, their own states." [emphasis added]

The right is clearly a reflection of the Constitution's implicit characterization of the Ethiopian federation as a unity created by the agreement of the Ethiopian nations, nationalities and peoples. As noted in the above section, these ethnic groups are given an unconditional right to self-determination up to secession. Indeed, the right to create regional states under Article 47 can also be considered as one aspect of the right to self-determination under Article 39. The latter provides for the protection of the right to self-determination including the right to self-administration (internal self-determination) and external selfdetermination (secession). A demand to create new regional state is obviously an aspect of the right to internal self-determination.

The holders of this right are obviously "nations, nationalities and peoples." As a result, the definition given to this expression is very essential to determine the nature of new regional states the establishment of which is permitted under the Constitution. As defined in Article 39(5) of the Constitution:

A "Nation, Nationality or People" for the purpose of this Constitution, is a group of people who have or share a large measure of a common culture or similar customs, mutual intelligibility of language, belief in a common or related identities, a common psychological make-up, and who inhabit an identifiable, predominantly contiguous territory.

One of the striking aspects of the above definition is that it does not differentiate between "nations", "nationalities" and "peoples". 51 One could, therefore, wonder why the three terms are used if they were ultimately to have the same definition. Leaving the definitional issue aside, the cumulative reading of Article 47(2) and Article 39(5) of the Constitution appear to limit the right to create new regional states only to groups which can be identified as "nation, nationality or people." As such, the Constitution does not seem to envisage the possibility of creating regions along non-ethnic lines. This is of course in line with the Constitution's general ethnic-centered orientation.

One could ask whether the expression "at any time" in Article 47(2) is intended to indicate the fact that such a right cannot be restricted even at a time of State of Emergency. The wording of the provision appears to support this interpretation. However, the constitutional provision on State of Emergency suggests otherwise. According to Article 93(4)(b), "the Council of Ministers

\footnotetext{
${ }^{51}$ See Christophe Van der Beken (2009), "Federalism and Accommodation of Ethnic Diversity: The Case of Ethiopia", Proceedings of the $3^{\text {rd }}$ European Conference on African Studies, at p. 11.
} 
shall have the power to suspend such political and democratic rights contained in this Constitution to the extent necessary to avert the conditions that required the declaration of a state of emergency." When sub-Article 4(c) of the same provision lists the rights which may not be suspended or limited by the emergency powers of the Council of Ministers, it only mentions Articles 1, 18, 25 and sub-Articles 1 and 2 of Article 39 of the Constitution.

Apparently, Article 47 (2) of the Constitution is not part of the list of provisions which are non-derogable. As such, there appears to be nothing that prevents the Federal government from suspending this right during a state of emergency. One could probably wonder if the right to create regional states under Article 47(2) should itself be non-derogable considering it is one aspect of the right to self-determination under Article 39(1) and (2). ${ }^{52}$ However, it should be noted that the list of non-derogable rights under Article 93(4)(c) did not include some of the sub-provisions in Article 39 itself. For example, Article 39(3) which talks about every Nation, Nationality and People's in "right to a full measure of self-government which includes the right to establish institutions of government in the territory that it inhabits ..." is not included in the list of nonderogable rights. In fact, the procedure for exercising self-determination up to secession under Article 39(4) is not also found in the list of non-derogable provisions. Therefore, if conditions that necessitate declaration of emergency are in place, the Federal Government can suspend the application of Article 47(2).

The right that is given to every NNP to create its own regional state is exercisable based on the procedures provided under Article 47(3). The procedures are also ethnic-centered in the sense that they do not give any decisive role to the federal government, or to the concerned State Council. According to the provision the right is exercisable:

a) When the demand for statehood has been approved by a two-thirds majority of the members of the Council of the Nation, Nationality or People concerned, and the demand is presented in writing to the State Council;

b) When the Council that received the demand has organized a referendum within one year to be held in the Nation, Nationality or People that made the demand;

\footnotetext{
${ }^{52}$ Apart from recognizing and institutionalizing the right of ethno-linguistic communities of Ethiopia to self-determination, making these right non-derogable during states of emergencies is one of the unique features of the FDRE Constitution. See Hashim Tewfik (2010), "Transition to Federalism: The Ethiopian Experience", Occasional Paper, Forum of Federations, at, p. 15.
} 
c) When the demand for statehood is supported by a majority vote in the referendum;

d) When the State Council will have transferred its powers to the Nation, Nationality or People that made the demand; and

e) When the new State created by the referendum without any need for application, directly becomes a member of the Federal Democratic Republic of Ethiopia. ${ }^{53}$

As it can be observed from the above provision, in the procedure for the creation of new regional States, it is the desire of the concerned people that plays a central role. There is an apparent resemblance in the secession procedure in Article 39 and the procedure for the establishment of new States in Article 47. In Article 39(4)(a), the procedure to exercise the right to self-determination, including secession, of every NNP shall be triggered "when a demand for secession has been approved by a two-thirds majority of the members of the Legislative Council of the Nation, Nationality or People concerned". Similarly, under Article 47(3)(a), the procedure for the exercise of "the right of any Nation, Nationality or People to form its own state" shall start "when the demand for statehood has been approved by a two-thirds majority of the members of the Council of the NNP concerned, and the demand is presented in writing to the State Council".

There is obviously a slight difference in wording in the above two provisions. While Article 39(4)(a) refers to the "Legislative Council of the Nation, Nationality or People", Article 47(3)(a) refers to "the Council of the Nation, Nationality or People concerned." One could wonder whether this implies a substantive difference in meaning. Article 39(4)(a) qualifies the term "Council" by adding the word "Legislative". It is not clear whether the "Legislative Council" referred to here is equivalent to "the State Council" referred to in Article 50(5) of the Constitution. In any case, a similar qualification is rightly absent in Article 47(3)(a). That is understandable considering the ethnic group demanding regional statehood will obviously be organized at a zonal or lower level of administration.

Even though the "Council" mentioned in Article 47(3)(a) plays a key role in the process of establishing a new state as the chief negotiator, the Constitution does not explicitly specify how it is established and who should serve on it. ${ }^{54}$ However, one can safely consider such "Councils" as results of the right of

\footnotetext{
${ }^{53}$ The requirements which are provided under Article 47(3) of the FDRE Constitution are also reproduced in Article 19(3) of Proclamation No. 251/2001 on Consolidation of the House of the Federation and the Definition of its Powers and Responsibilities.

${ }^{54}$ See Tom Pätz (2005), 'Ethiopia (Federal Democratic Republic of Ethiopia)', in Ann L. Griffiths (ed.), Handbook of Federal Countries, McGill-Queen's Press-MQUP, at p. 139.
} 
every Nation, Nationality and People to "a full measure of self-government which includes the right to establish institutions of government."

Be this as it may, the demand for regional statehood that is raised and discussed in the Council of the Nation, Nationality and People should be approved by a two-thirds majority. Although the two-third majority requirement is normally a high threshold, it is not difficult to achieve it in a campaign that is driven by nationalist sentiments. Once the demand for a regional Statehood is approved by a two-thirds majority in the Council of the concerned Nation, Nationality or People, it should then be presented in writing to the State Council. ${ }^{56}$ The Constitution does not seem to give the State Council an option to reject the question. Rather, the State Council is expected to organize "a referendum within one year to be held in the Nation, Nationality or People that made the demand." [emphasis added] Despite putting this very short time frame, the Constitution did not specify the possible consequence of failure to organize referendum within one year.

Article 19(3)(2) Proclamation No. 251/2001 tries to fill the gap by ensuring the right to appeal to the House of Federation which can be exercised by the party which claims that its demand for regional State formation has not been executed within the time specified or alleges to have dissatisfaction with the decision. Such complaint has to be presented to the House in writing by the Council of the NNP that claimed for the formation of State. ${ }^{57}$ The House is then expected to give final decision on the issue within two years after receipt of the complaint. $^{58}$

The above provisions of Proclamation No. 251/2001 seem to imply the intention to relax the rather strict procedure of the Constitution. As mentioned above, if the two-third majority is achieved in the Council of NNP demanding to form its own state and if the demand is presented in writing, the Constitution does not seem to give the State Council the right to reject the request. Proclamation No. 251/2001, however, does not only envisage the possibility of

\footnotetext{
${ }_{55}^{55}$ See Article 39(3) of the FDRE Constitution.

${ }^{56}$ A similar requirement is not clearly indicated in Article 39 in the case of a demand for secession. However, Article 39 (4) (b) indicates that a similar requirement is applicable. The provision implies this while entrusting the duty to organize a referendum to the Federal Government. The provision reads: "When the Federal Government has organized a referendum which must take place within three years from the time it received the concerned council's decision for secession." The organs that would receive the demand for secession and regional statehood are however different. In the case of the demand for secession under Article 39, the request is presented for the Federal Government.

${ }^{57}$ See Article 9(3)(3) of Proclamation No. 251/2001.

${ }^{58}$ Ibid, Article 9(3)(4)/
} 
the referendum not being conducted within one year, it also gives the House two years to consider the appeal. Apparently, the Proclamation gives more time for the House to consider the appeal than the timeframe to organize the referendum given (to the State Council) under the Constitution. Although the additional procedures included in Proclamation No. 251/2001 seem to indicate the lawmaker's recognition of the unreasonably strict nature of the Constitution's one-year time frame, their constitutionality can be questioned.

This issue was raised recently in the context of the Sidama quest for regional statehood when a referendum was not organized within the constitutionally specified one-year period. Many agitators for Sidama regional statehood were of the view that the failure to organize referendum within the one-year period entitles them to declare regional statehood unilaterally. Although the threat was not actually acted upon, the violence that ensued in the region amidst the controversy has indeed put the problematic nature of constitutionally provided procedure into a spotlight. ${ }^{59}$

A problem one can notice in the procedure for the creation of new regional states is the fact that the issue is exclusively left to the ethnic group raising the demand. The Constitution is designed with the assumption that ultimate sovereignty lies on each nation, nationality and people, and the freedom to form one's own state at any time appears to have been used as a mechanism to entice the various ethnic groups to be included in the original nine states. ${ }^{60}$ The Constitution does not envisage the need for the involvement of the Federal Government or regional states. It is as if there is nothing whatsoever in the creation of new states that would affect the other regions or the country as a whole. As highlighted in the next section, this purely ethnic-centered approach embodied in the Ethiopian Constitution is in stark contrast with procedures for the creation of new states enshrined in other federal constitutions.

\section{Creation of New States in Other Federal Constitutions}

Constitutions of many federal countries deal with the issue of creation of new states. A cursory overview of the provisions dealing with the issue of creation of new states in various federal constitutions exhibits that, these constitutions are different from the FDRE Constitution at least in one important respect. Almost

\footnotetext{
59 To avoid similar problems, the State Council of the SNNPR has reportedly been deliberately avoiding receiving the written decisions from the other Zonal nationality Councils by not convening for several months. Regarding the case of Sidama, the Election Board has decided November 13, 2019 to be the date for the popular referendum. $<$ https://www.africanews.com/2019/08/29/ethiopia-slates-november-13-for-sidamaautonomy-referendum//>

${ }^{60}$ See Nigussie Afesha Aytaged, supra note 49, at p. 240.
} 
all constitutions considered in this research put limitations on the creation of new constituent units by allowing federal parliaments and/or other concerned constituent units to have a say in the process. A quick overview (in Section 3.1) of the relevant provisions of the constitutions of some randomly selected federal and quasi-federal countries such as the USA, Australia, South Africa, Brazil, Pakistan, Mexico, Germany and Switzerland can provide excellent examples to elaborate the general trend. Section 3.2 focuses on the history of state creation in two purposively selected ethnically diverse countries, namely, Nigeria and India. Their experience shows the sensitivity and complexity of the state creating exercise, and the constitutional procedures for the creation of new states in these countries are in line with the general trend that gives the Federal government a decisive role in the process.

\subsection{General overview}

Due to the history of the American Federation as a coming together federalism, the Constitution was more open to the admission of new states to the Union than the creation of new states from already existing ones. Section 3 of the American Constitution provided that "new states may be admitted by the Congress into the Union." However, it prohibited the formation of new states "within the jurisdiction of any other State." It also prohibits the formation of new states "by the Junction of two or more states, or parts of States without the consent of the Legislatures of the States concerned as well as of the Congress."

In comparison to the US Constitution, the Australian Constitution follows a more open approach to the creation of new states from already existing ones. Nevertheless, the federal parliament has still a role to play in the creation of new states. Besides, the states that are affected by the creation of the new state also have a say. According to Article 123 of the Constitution of Australia, "[a] new State may be formed by separation of territory from a State, but only with the consent of the Parliament thereof, and a new State may be formed by the union of two or more States or parts of States, but only with the consent of the Parliaments of the States affected." In formal terms, although it is the State Parliament that will decide on the issue, a referendum would be most likely. ${ }^{61}$ According to the Australian model, therefore, the creation of a new state requires gaining the consent of the majority of residents in the region where the new state is to be formed. ${ }^{62}$

Under the South African Constitution, the issue of creating new provinces or merging the already existing ones is treated as a question of constitutional

\footnotetext{
${ }^{61}$ See Kenneth Wiltshire, "Reforming Australian Governance: Old States, No States or New States?" in Federalism and Regionalism in Australia, at p. 197.

${ }^{62}$ Ibid.
} 
amendment. Accordingly, alterations to "provincial boundaries, powers, functions or institutions" are subject to the amendment procedure of Section 74(3)(ii) of the Constitution that requires the approval of two-thirds of the National Assembly and six provinces in the National Council of Provinces. In addition, the proposed alterations should also be approved by the provincial legislatures in question. ${ }^{63}$

In Brazil's Constitution ${ }^{64}$, Article 18 provides three main modalities for the creation of new states, i.e. merger of already existing states, subdivision, or annexation. ${ }^{65}$ The Brazilian Constitution envisages the possibility of considering the views of the population in the counties involved. However, here too, the final say is reserved to the National Congress.

Giving a role to the national parliament in the creation of new states can also be observed in Pakistan's Constitution. Article 1(3) of Pakistan's Constitution of 1973, give the Majlis-e-Shoora (Parliament), the power to admit (by law) "into the Federation new States or areas on such terms and conditions as it thinks fit."

Similarly, in Mexico, the Federal Government plays a role in the creation of new states. However, the procedure of state creation in the Mexican Constitution has more rigorous requirements. According to Article 73 of the Constitution of Mexico (1917 (rev. 2015)), admitting new states into the Union (Art 73(I)) and "creating new states within the limits of the existing ones" (Article 73(III)) are within the power of the Congress. In addition to giving the power to decide on the creation of new states for the Congress, the Constitution lists various requirements that should be met. The requirements include: population size, viability, report about usefulness or inappropriateness of creation of new states and voting in each house. ${ }^{66}$

In the procedure for the creation of new states in the Mexican Constitution, there is emphasis on examining the usefulness of the creation. There is the need to approve the proposal by two-thirds of the votes in each House, and the majority of the state legislatures are expected to approve it. The procedure acknowledges that the creation of new states is an issue that could affect the whole nation.

Germany emphasizes on efficiency arguments for the creation of a new state. Article 29 of its constitution (Basic Law) provides that the federal units

${ }^{63}$ See Section 74(8) of the Constitution of South Africa.

${ }^{64}$ Though it has oscillated between centralized and decentralized political governance, Brazil has started to experiment Federalism starting from the 1890s'. See in general Keith S. Rosenn (2005), "Federalism in Brazil”, Duquesne Law Review, Vol. 43, pp. 577598.

${ }^{65}$ See Article 18, par. 3 of the Constitution of Brazil.

${ }^{66}$ See Article 73 (III) of Constitution of Mexico. 
(Länders) that constitute the federal territory "may be revised to ensure that each land be of size and capacity to perform its functions effectively." ${ }^{, 67}$ Besides, the constitution also gives due regard to "regional, historical and cultural ties, economic efficiency and the requirements of local and regional planning" in the creation of new Länder. ${ }^{68}$

The procedure for the creation of new Länder in Germany is referendumbased and it can be initiated by the federal parliament or by petition of $10 \%$ of the voters in a contiguous area. ${ }^{69} \mathrm{~A}$ major issue in the creation of new states is whether already existing states affected by a potential loss of territory have a say on the proposal to establish new state. ${ }^{70}$ Germany requires the consent of the affected state from whose territories or parts of territories a new land or land with redefined boundaries to be established. ${ }^{71}$ More specifically, Article 29(3) of Germany's Constitution (Basic Law) provides that a proposal to create a new state can be vetoed by a two-thirds majority in the territory of the affected land as a whole.

As mentioned earlier in the introduction, Switzerland has a stable federalism with respect to the number of the constituting federal units (Cantons) ${ }^{72}$ other than the creation of the Canton of Jura in 1979, which necessitated clear constitutional guidelines or rules on how to create a new state. ${ }^{73}$ Article 53 of the current Federal Constitution of the Swiss Confederation that deals with the "number and territory of the Cantons" has been added due to the Jura experience. ${ }^{74}$ According to the provision, preserving the existing number of Cantons and territories appears to be the preferred position. Sub-article 1 states that "the Confederation shall protect the existence and territory of the Cantons." Creation of new Cantons is therefore subject to stringent requirements. It "requires the consent of the citizens of the Cantons concerned together with the consent of the People and the Cantons." 75 This means, apart from the consent of the citizens of the Cantons concerned, the proposal should get a majority

\footnotetext{
${ }^{67}$ Article 29(1) of Constitution of Germany.

${ }^{68}$ Ibid.

${ }^{69}$ Ibid, Art 29 (4).

${ }^{70}$ See George Anderson, supra note 50,atp. 18.

${ }^{71}$ See Article 29 (3) of Constitution of Germany.

${ }^{72}$ See Thomas Fleiner (2009), “The Curent Situation of Federalism in Switzerland”, Revista d'estudis autonòmics i federals, Vol. 9, pp. 65-66.

${ }^{73}$ Ibid.

${ }^{74}$ See Tina Kempin Reuter, supra note 3, at p. 260.

${ }^{75}$ See Article 53(2) of the Swiss Constitution.
} 
support in a country-wide referendum and the majority of the Swiss Cantons should support it. ${ }^{76}$

In all the constitutions considered above, the issue of creating constituent units is nowhere completely left to the decision of the group/region that raised the question. As highlighted below, similar trends are observed in the Indian and the Nigerian constitutions which manage ethnically diverse entities like Ethiopia.

\subsection{Creation of new member states in ethnically diverse federations: examples of Nigeria and India}

\subsubsection{Nigeria}

Nigeria is a highly diverse country with over 374 ethno-lingual groups, each with its distinguishing culture and tradition. ${ }^{77}$ Before the advent of colonial rule, these ethnic groups were either encapsulated in the major kingdoms and empires which comprised the area or were resisting annexation by those empires and kingdoms. ${ }^{78}$ The situation ended when all these ethnic groups were conquered by the British and included into one entity. ${ }^{79}$

Some writers identify several stages in the evolution of the Nigerian federal character. These stages include: the period of informal federation 1900-1946; the first phase of formal federation, 1946-1966; and the second phase of formal federation, 1967- present. ${ }^{80}$ Except for a brief period in 1966 when the military decreed a unitary system of government, federalism remained part of Nigeria's political system. $^{81}$

${ }^{76}$ This is clear from Article 142(2) of the Swiss Constitution that defines what 'vote of the People and Cantons' mean. The provision reads: "Proposals that are submitted to the vote of the People and Cantons are accepted if a majority of those who vote and a majority of the Cantons approve them."

${ }^{77}$ See E. Okpanachi \& A. Garba (2010), "Federalism and Constitutional Change in Nigeria", Federal Governance, Vol.7, No. 1, at p. 3.

${ }^{78}$ See Auwalu Musa \&Ndaliman Alhaji Hassan (2014), "An Evaluation of the Origins, Structure and Features of Nigerian Federalism", The International Journal of Social Sciences and Humanities Invention, Volume 1, Issue 5, at p. 314.

79 See Okonkwo C. Ezel, Alexander Elimian1 \& Uchenna G. Chinwubal (2015), "The Politics of State Creation and National Integration in Nigeria", Journal of Politics and Law, Vol. 8, No. 1, at p. 113.

${ }^{80}$ See Philips O. Okolo (2014), "Influence of the Federal Character Principle on National Integration in Nigeria", American International Journal of Contemporary Research, Vol. 4, No. 6, at p. 122. See also Cornelius, O. Okorie, and Esheya Greg (2013), "Federal Character Principles, Nation Building and National Integration inNigeria: Issues and options", Mediterranean Journal of Social Sciences, Vol. 4., No 16, 2013.

${ }^{81}$ Okpanachi \& Garba, supra note 77. 
However, the nature and structure of Nigerian federation has gone through significant changes over the years. Part of the change occurred in the form of an increase in the number of the members of the federation. When the British formally introduced a federal structure of government in the 1946, Richard's Constitution ${ }^{82}$, they divided the country only into three unequal regions. As a result, at independence, Nigerian Federation still had only three major regions (Northern, Eastern \& Western Regions) and a 'Federal Capital Territory' of Lagos. However, due to changes in subsequent years, the Nigerian federation was transformed from a highly decentralized country with three large regions to a highly centralized one with 36 states and a Federal Capital Territory. ${ }^{83}$

Agitations for the creation of new states are almost as old as the Nigerian nation. ${ }^{84}$ Although questions for decentralization in the form of creating new states and local governments continue to be raised even before independence in $1960^{85}$, the idea was rejected "because of the difficulty in drawing a 'clean' boundary which "does not create fresh minority", among others." Willink Commission was instituted in 1957 to enquire into the fears of the minorities and suggest the means of allaying them. The Commission found evidence of discrimination and other problems alleged by the minorities, it acknowledged the genuineness of their fears and anxieties, and concluded that the solution to the problem of minorities lies in the political process, rather than the creation of separate States for them. ${ }^{87}$

Since independence, however, numerous states and local governments have been created. The three regions at independence have now been partitioned into 36 states, a 'federal capital territory' and seven hundred and seventy-four Local Government Areas. ${ }^{88}$ A unique feature of the Nigerian state creation exercise is that the military has affected the structural transformation of the federation. ${ }^{89}$

${ }_{83}^{82}$ See Philips O. Okolo, supra note 80, at p. 122.

${ }^{83}$ See Okpanachi \& Garba, supra note 77.

${ }^{84}$ See Okonkwo C. Eze1, Alexander Elimian1 \& Uchenna G. Chinwubal (2015), supra note 79.

${ }^{85}$ See Agboola Theophilus Olumuyiwa (2016), "The Challenges of State/Local Government Creation in Nigeria: A Critical Analysis", International Journal of Politics and Good Governance, Volume VII, No. 7.1 Quarter I, at p. 2.

${ }^{86}$ See Isawa Elaigwu (2005), The Politics of Federalism, Aha Publishing House, Jos, at p. 23.

${ }^{87}$ See Philip TerzungweVande, "Ethnicity and the Politics of State Creation in Nigeria", European Scientific Journal, Vol. 8, No.16, at p. 39.

${ }^{88}$ Ibid.

${ }^{89}$ See Abdul-Majeed Alkali (2017), "Federalism and the Creation of Sub-national States in Nigeria: Appraising the State-Creation Exercise Under Babangida Administration", IOSR Journal of Humanities and Social Science, Vol. 22, Issue I, at p. 1. 
This is not surprising considering, in Nigeria, military rule was the vogue rather than an aberration, given the fact that, in Nigeria's first twenty-one years of sovereign statehood, the military was in power for thirteen years. ${ }^{90}$ Thus, the majority of state creation exercises in Nigeria were solely undertaken by the military. The only time that a civilian government created a sub-national unit was in 1963 when the Mid-West Region was carved out of the defunct Western Region". 91

It was not because agitations for state creation were absent that civilian administrations did not create many states. In fact, as one writer put it:

The question of creation of states was one knotty problem that the Shagari led civilian administration had to contend with. States creation was especially popular during the Second Republic, with virtually every politician championing the creation of additional constituent units in their localities. In the event, the country was abuzz with state creation movements. So emotive and compelling was the advocacy for more states that two separate committees on state creation had to be set up in 1982. First to be set up was the House of Representatives Committee on State Creation. The other committee was constituted by the then President Shagari, who considered it his responsibility as the President to try to bring in consensus and understanding, and to project his party's position on the state question. ${ }^{92}$

Even though the committees on state creation recommended the creation of additional states, due to intense politicking, it was not possible for the civilian administration during the Second Republic to create new states before it was overthrown in a military putsch in December $1983 .{ }^{93}$ The process of creating states under civilian administrations was further saddled with constitutional bottlenecks. ${ }^{94}$ Military regimes, however, were not restricted by constitutional limitations. Besides, military governments also tend to use creation of new states to gain popular support. ${ }^{95}$ As a result, it is during military regimes that most of the 36 members of Nigerian federation were created.

One may, however, wonder why questions for the creation of new states arise. Various arguments are advanced to justify requests for state creation in Nigeria. In earlier times, state creation was advanced as a means to tackle the

\footnotetext{
${ }^{90}$ Ibid.

${ }^{91}$ Ibid.

${ }^{92}$ Ibid, at p. 4.

${ }^{93}$ Ibid.

${ }^{94}$ Ibid at p. 2.

${ }^{95}$ See Dele Adetoye \& Mike Apeyemi Omilusi (2016), "Ethnicity, Federalism and State Creation in Nigeria: Exploring Political Economy as a theoretical Framework", European Journal of Research in Social Sciences, Vol. 4, No. 5, at p. 24.
} 
menace of majority domination over minorities. ${ }^{96}$ However, ethnicity and economic considerations appear to be more important drivers for the state creation exercise in Nigeria. According to Suberu "distributive pressures lie at the roots of the clamour for new subnational units in Nigeria." He observes that the Nigerian federal system explicitly legitimates and accommodates sectionalterritorial constituencies, and thus "provides the structural and institutional framework for the organisation and mediation of the ethnic competition for public resources in Nigeria." 97 Ethnicism and the role of ethnic elites in agitations for the creation of new states should not also be ignored. In this regard, Adetoye observed:

The purpose of federalism and state creation as devices for decentralization for the purpose of effective governance and service delivery has been sacrificed on the altar of ethnicism and ethnic representation. Rather than seen and used as a dispassionate tool of developmental administration, these political units (states) into which the Nigerian federation has been divided, have become instruments of negotiation for patronage by the ethnic elite and the ruling class. ${ }^{98}$

The above concern is specifically relevant in the Ethiopian situation considering the Constitution's highly ethnic-centered approach that leaves the decision for creation of new states for the NNP that raised the question. As noted in the above discussion, the expansion of the members of the Nigerian federation has primarily occurred by military governments. However, we should still consider the procedure for the creation of new states in the Nigerian Constitution and see if it is fundamentally different from those which have been considered above. According to Part II (8)(1) of the Nigerian Constitution (as revised in 1999):

An Act of the National Assembly for the purpose of creating a new State shall only be passed if-

(a) a request, supported by at least two-thirds majority of members (representing the area demanding the creation of the new State) in each of the following, namely - (i) the Senate and the House of Representatives,

(ii) the House of Assembly in respect of the area, and (iii) the local government councils in respect of the area, is received by the National Assembly;

\footnotetext{
${ }^{96}$ See Dele Adetoye (2016), "Ethnicity and State Creation In Nigeria: Exploring The Nexus Between The Babel Of Tongues And Institutionalization", International Journal of Economics, Commerce and Management, Vol. IV, Issue 4, at p. 4.

${ }^{97}$ Cited in Abdul-Majeed Alkali, supra note 89, at p. 2.

${ }^{98}$ See Dele Adetoye, supra note 96, at p. 10.
} 
(b) a proposal for the creation of the State is thereafter approved in a referendum by at least two-thirds majority of the people of the area where the demand for creation of the State originated;

(c) the result of the referendum is then approved by a simple majority of all the States of the Federation supported by a simple majority of members of the Houses of Assembly; and

(d) the proposal is approved by a resolution passed by two-thirds majority of members of each House of the National Assembly.

As can be observed from the above provision, a request for state creation should be supported not only by those demanding it, but also by other members of the federation and a two-thirds majority of members of each House of the National Assembly. Like the constitutions of various federal countries considered above, the procedure enshrined in the Constitution of Nigeria indicates that state creation exercise is not understood as a right that can exclusively be exercised only by those who raised it.

\subsubsection{India}

The territorial evolution of the Union of India has gone through several changes in the course of the past seven decades. The Constitution of India adopted on $26^{\text {th }}$ January 1949 conceived the Union as indestructible. ${ }^{99}$ The same Constitution, however, has opened the door for the admission of new territories or creation of new states into the union, or the establishment of new States. The parliament has the power to "form a new State by separation of territory from any State or by uniting two or more States or parts of States or by uniting any territory to a part of any State" (Art. 3, Constitution of Union of India 1949)

The Indian federal system which started with 14 States and 6 Union Territories has now expanded to 29 States and Seven Union Territories. ${ }^{100}$ Unequal regional development, identity, autonomy, good governance or political participation are some of the driving factors leading to the proliferation of new states in India. ${ }^{101}$ The demand for the recognition of new states within the Union of India is challenging given the linguistic and cultural diversity of the country. The Constitution does not provide indicative principles for the recognition of new states. Different committees have been established to overcome this challenge. At the early stages of the Indian Federal System, for example, various committees were established to examine the federal

\footnotetext{
${ }^{99}$ See Raghuvansh Suvir (2016), "Creation of New States in India”, Bharati Law Review, at p. 164.

${ }^{100}$ See supra note 1 .

${ }^{101}$ See Naik Susant Kumar, and V. Anil Kumar (2016), "Federalism and the Formation of States in India, Institute for Economic Change", Working Paper 378, at p. 3.
} 
Structure. ${ }^{102}$ The State Restructuring Committee (SRC) established in 1953, specifically, has made significant contributions by identifying concrete considerations for the recognition of new states within the Union of India. ${ }^{103}$

The main parties involved for the creation of new states as stipulated in the Constitution are the president, the parliament, and the legislature of State/s. The role of the President in the process of state creation is extensive. It is not the legislature of the state but the president who has the power to introduce a Bill for the creation of new states in either houses of the parliament.

It is more likely that the proposed Bill for such effect may have elements that affect the interest of one or more states within the Union. If it is so, the President is required to refer it to the legislature of the concerned State for expressing its views. The Legislature of the State, on its part, may express its views within the time limit stipulated in the reference or a period set by the president. Although the Constitution puts a mandatory requirement on the president to seek an opinion from the concerned state legislature/s, it is up to the legislature to give or not to give its views on the matter. The failure of the legislature to provide its views within the time limit set does not stop the procedure of state creation.

States have a marginal role in the creation of new states since the Constitution limits their engagement in terms of non-binding opinion. The decisive engagement of the parliament in the creation of new states while keeping Legislature of States at the margins could be the manifestation of the "holding together" model of federalism that characterizes the Indian federal structure.

The expanded role of the president and the limited engagement of the state legislature in the creation of new states are justified by the rights of minorities. During the making of the Constitution, there was deliberation on the question of who should be empowered to initiate the process of state creation. There was a proposal (such as an argument made by Prof. K T Shah) that the Bill for the creation of a new state should originate from the State legislature "whose boundaries are proposed to be altered, or whose areas are proposed to be increased or diminished"

Any question which relates to the alteration of the present units, their territories, boundaries or name, should begin with the people primarily affected, and should not come from the authority or power at the Center. ${ }^{104}$

\footnotetext{
102 Ibid.

${ }^{103}$ Linguistic, cultural homogeneity and geographical contiguity are some key considerations highlighted by the SRC for recognizing demand for the creation of new states.
} 
K. T. Shah argued that a bottom-up approach gives the opportunity to consult the legislature directly affected instead of imposing it from above. The fundamental democratic principles demand consulting the people affected. Laying it down from above put excessive power in the parliament and contravenes the very idea of democracy embodied in the Union's Constitution.

The honorable Shri K. Santhanam on his part opposed the amendment proposed by K. T. Shah claiming that the empowerment of the State legislature would mean that "no minority in any State can ask for separation of territory, either for forming a new province or for joining an adjacent State unless it can get a majority in that State legislature". Moreover, Shri contended that giving the power to the State legislature would create the tyranny of the majority in every province and state, instead of democracy. ${ }^{105}$

K. T. Shah's proposal did not make it to the constitution on the justification that the procedure may contravene against the interest of minorities in those regional States dominated by a majority group. Giving the power to the president was considered friendlier to minority groups seeking their own new states from any region of States.

Another important consideration in the procedure for the creation of new states under the Indian federal system is the voting rule. Given the intensity of the matter, one may expect a special voting rule to such effect. The Constitution, however, provides no special voting rule. A simple majority of the members present and voting in the parliament suffice to determine the creation of a new state in the Union (in accordance with Article 100, Indian Constitution).

One could wonder whether a similar concern regarding minority protection could be raised in the Ethiopian context due to the lack of involvement on the part of the federal government in the creation of new states. In our view, such concern cannot occur in the Ethiopian context because the regional states merely have a facilitative role in the creation of new states. The relevant provisions in the Ethiopian Constitution do not suggest any say by the regional administration in the decision-making process. The concern in the Ethiopian context rather lies in giving the right to establish a new state for the 'nation, nationality or people' demanding it. This approach is not in conformity with the comparative experience and good practices followed in most federal constitutions. The Ethiopian approach has actually ignored many important considerations that should have been taken into account in the process. That is where the real concern lies.

\footnotetext{
${ }^{104}$ See Constituent Assembly of India Debates (Proceedings)(1948)- Volume VII, Wednesday, the $17^{\text {th }}$ November.

${ }^{105}$ Ibid.
} 


\section{Overlooked Issues in the FDRE's Constitution Ethnic- centered Approach}

As the discussion in the above section could make clear, the procedure for the creation of new states under the FDRE Constitution solely focuses on the desire of the "nation", "nationality" and "people" that demands it. With its sole focus on ethnicity and no external procedural or substantive limit on the exercise of the right, the Constitution overlooks some important issues with non-negligible consequences. As Section 4.1 indicates, unlike some of the federal constitutions reviewed above, the FDRE Constitution does not address the issue of merger. It rather focuses on the possible creation of new smaller ethnic-based states in a procedure that leaves the ultimate decision to the ethnic group that raised the question. This procedure provides very limited room for objective considerations related to economic viability and administrative efficiency (Section 4.2). It is to be noted that there is almost no guarantee to ensure equity both in the process and outcome (Section 4.3). The exercise of the right by one ethnic group is likely to have a demonstration effect which triggers further fragmentation (Section 4.4). Moreover, Section 4.5 discusses the effect of the creation of many new states which is likely to have an unintended impact of making the amendment of the FDRE Constitution practically more rigorous, thereby potentially creating minority tyranny.

\subsection{Lack of clarity on the procedure for merger}

Some of the federal constitutions discussed above provide not only procedures for the creation of new states from already existing ones, but also envisage the possibility of creating a new state by merging two or more states or by taking parts of two or more already existing States. Some constitutions also leave the door open for other states to join the union. The Ethiopian constitution is silent on these issues and fails to answer several important questions.

First, can two or more existing states merge to form a new state? For example, can adjacent regions such as Harari and Oromia, or Amhara and Beneshangul, etc decide to merge and create a new region? Second, is it possible to divide existing States on non-ethnic lines to create new regional states? For example, is it possible the bigger regions such as Oromia, Somali region and Amhara be divided into several regions? Third, can people living in two regional states adjacent to one another form a separate region? For example, can the Guji Oromos and Gedeos decide to form a separate new regional state?

As noted above, it is clear that the FDRE Constitution does not directly deal with the issue of merger of various states to create new ones. However, considering that some of the already existing states of the federation are clearly multi-ethnic, the Constitution does not prohibit the creation of bigger multiethnic regions. However, with no clear procedure to be followed, it is not clear 
how this could be constitutionally materialized. For example, if a newly created state wants to get back to its former regional state, what procedure would be followed? Can the procedure that is pursued for the creation of new states be used to reverse the decision?

The issue of creating new states on non-ethnic lines does not seem to be supported by the spirit of the Constitution. By making "nations, nationalities, or peoples" the holders of the right, the Constitution appears to have excluded the possibility of asking for separate regions on non-ethnic grounds. By the same token, the Constitution does not seem to permit the creation of multiethnic regions by taking territories from already existing national regional states.

\subsection{Absence of objective considerations related to economic viability and administrative efficiency}

The ethnic-centered approach for creation of new states under the FDRE Constitution gives every nation, nationality or people the right to form its own regional state irrespective of its number. On the other hand, the Constitution does not provide a clear procedure for a possible creation of non-ethnic regions for reasons such as administrative efficiency. By following this approach, the Constitution appears to assume every ethnic group not just as a cultural unit but also a natural economic and administrative unit. The democratic process is limited within the ethnic group in which the question is raised, and there is no other way to ensure that considerations related to economic viability, administrative efficiency and more generally the usefulness of creating new state are properly made.

\subsection{Lack of guarantee to ensure equity in outcomes and process}

The creation of a new state within the federal structure undoubtedly results in a change in the boundaries of already existing states. More specifically, the State within which the demand for statehood is sought will be directly affected by the alteration of territorial boundaries. Consulting the council of those states, whose boundaries and interests are to be altered would be the proper course to ensure equity in the process and outcome of new state creation.

The constitutional provision that dictates the procedure for the creation of new states, however, puts greater emphasis on the NNP seeking statehood than other stakeholders affected by the process and outcome. The power to initiate the demand for the creation of a new state is given exclusively to the NNP. Once the demand for statehood is approved by a two-thirds majority of the members of the Council of the NNP concerned, the Constitution requires the demand to be presented in writing to the State Council. Neither the State Council nor the Federal government has the power to propose the creation of a new state. This approach puts excessive power in the hands of the NNP, to the prejudice of the concerned State or the country as a whole. It severely impedes 
the State and Federal government of any attempt to create a new state or amalgamate already existing ones for economic or any other pragmatic reasons.

Moreover, the extent to which the State Council reflexes its muscles on the demand of statehood is not clear. It is vague under the Constitution whether the state council has the power to vote on the demand submitted in writing or directly proceed with the referendum. According to Article 47(1)(b) of the Constitution, the State Council that received the demand for the creation of a new state has the responsibility to organize a referendum within one year to be held in the NNP that made the demand. If no deliberation is made in the State Council for accepting or rejecting the statehood demand, the role of the concerned State will be very symbolic and minimal in the outcome. The position of the Constitution is very clear that the NNP are the true sovereignty holders and States are not. The Constitution seems consistent in this regard for giving excessive power to the concerned NNP in the creation of new states, while keeping the role of the State Council at the margin.

The Constitutional choice of starting the process of state creation from the initiatives of the NNP (that is primarily concerned) is not a problem per se. This bottom-up approach could be friendlier to the fundamental democratic principles and the sovereign power holders as enshrined in the Constitution. However, the absence of express cautions in the course of the creation of new states deviates from the very purpose of institutionalization.

Creating a new state may be embarked upon irrespective of its negative externalities. For example, the self-interested choices of that group to form a new state may contradict the interest of the nation as a whole or at times may result a situation where the majority of NNPs do not prefer. ${ }^{106}$ As much as protecting the right of a given NNPs to create its own new state is relevant, the interest of other NNPs in the concerned State or adjacent State/s whose interests are directly or indirectly affected by the potential alteration should also be equally respected for the sake of horizontal equity. In this regard, the Constitution does not provide procedural safeguards to protect the interest of NNPs which may be potentially affected by the demand for the creation of a new state. Apparently, it would have been more reasonable, at least, to allow other NNPs affected by the demand to express their views.

${ }^{106}$ Institutions, partly, are there to employ sanctions to shape the choice of strategies in the best interest of the constituting members and the group to transcend problems of collective actions which often fall to collective dilemma problems. See R. H. Bates (1988), "Contra Contractarianism: Some Reflections on the New Institutions", Politics \& Society, Volume 16, Issue 2-3. 


\subsection{The demonstration effect, risk of fragmentation and territorial and boundary related conflicts}

The right-based approach for the creation of new states with no meaningful external limitation poses the risk of continuous fragmentation. This risk is exacerbated by what political scientists call "demonstration effect." This issue is usually discussed in connection with the principle of national selfdetermination. Scholars argue that the application of self-determination by one group would have destabilizing effect for the international system as it could license a secessionist free-for-all and lead to the break-up of most of the world's States. ${ }^{107}$ A similar problem can obviously be envisaged regarding the state creation procedure in the FDRE Constitution. The signs in Ethiopia's SNNPR point to that direction. Following the Sidama quest for regional statehood, other zonal administrations have reportedly followed suit asking for their own regions.

The demonstration effect does not end there. When the self-determination of one ethnic group is viewed as compromising the self-determination of another ethnic group, minorities living within the region of that ethnic group could strive to achieve self-determination for themselves. This, in turn, creates a potential for conflict and/or the creation of pockets or enclaves of administrative units that are not viable.

The risk of boundary-related conflicts should be seen in light of the already existing growing incidents of ethnic conflict over identity and territorial issues. A proliferation of new states following the ethnic-centered approach enshrined in the Constitution might exacerbate this problem. Since the approach denies other concerned groups to have a say in the process of state creation, the disagreements on the need of creating new states might be manifested in the form of territorial disputes. In regions like the SNNPR, with numerous regional statehood questions being raised at a time, the capacity of a potentially disintegrating regional administration -to solve interethnic disagreements over territory- is likely to be limited.

\subsection{Impact of creation of new states in the constitutional amendment procedure}

The ethnic-centered approach for the creation of new states in the FDRE Constitution has the potential of creating as many regional states as the number of ethnic groups in Ethiopia. Although one could think of the possible democratic and developmental benefits that could come with the introduction of

${ }^{107}$ See Margaret Moore, 'Introduction: The Self-Determination Principle and the Ethics of Secession', in Margaret Moore (ed.) (1998), National Self-Determination \& Secession, Oxford, Oxford University Press, at p. 4. 
smaller states -in contrast to the current big regional states,- it cannot be ignored that such benefits cannot be distributed in a balanced way throughout the country. This is because the Constitution does not as such recognize the possibility of creating new states on non-ethnic lines for the purpose of administrative efficiency.

This reality has the potential of giving disproportionate power to smaller ethnic groups which create new states in the constitutional amendment procedure. This is because, according to Article 105 of the FDRE Constitution, for the purpose of amending the provisions of the Constitution in Chapter three, the consent of all the State Councils is required. In other words, the more new states are created in the federation; the more rigorous the amendment procedure would become. Considering the very controversial nature of some of the provisions of the Constitution, this does not seem to be desirable. For example, a constitutional change that may be desired by over $90 \%$ of the population might be prevented by a very small region.

\section{Concluding Remarks}

The procedure for the creation of new regional states in the FDRE Constitution is highly ethnic-centered. That is unsurprising considering the Constitution's provisions that empower every NNP in Ethiopia to have an unconditional right to self-determination up to secession. It is this radical stance on selfdetermination that has shaped the content and procedure of the right to create new regional states in the FDRE Constitution.

According to Article 47(2) of the FDRE Constitution, every NNP has a right to form its own regional state. Once the demand for statehood is approved by a two-third majority of the Council of the NNP and presented in writing to the State Council, the latter should organize a referendum within one year. If, in the referendum, the majority of the concerned NNP votes in support of forming a region, the NNP will become a new member of the federation.

In this procedure, neither the federal government nor concerned regional states have substantive role that could affect the outcome of the process. With its sole focus on the rights and the interests of the NNP requesting regional statehood, the procedure ignores several important concerns. First, the constitutional procedure appears to have excluded the possibility of creating new states on non-ethnic lines based on considerations of economic and administrative efficiency, capacity to perform state functions effectively, or requirements of regional planning. ${ }^{108}$ The apparent absence of a procedure for merger also gives the impression that the drafters of the Constitution focused

\footnotetext{
${ }^{108}$ See Article 29 of the Constitution of Germany.
} 
more on possible fragmentation than consolidation. Considering that most of the original nine states were multi-ethnic, merger should have been considered as one possible expression of the right to self-determination.

Second, even when the quest for creation of new states comes from an NNP, the task of making objective considerations related to economic viability and administrative efficiency is left to the ethnic group raising the question. If the democratic process within that NNP fails to ensure the proper consideration of these concerns, the constitutional procedure does not put any other safeguards. It is as if the Constitution considers each ethnic group as a natural economic and administrative unit.

Ethiopia's ethnic-centered constitutional approach gives little attention to the possible adverse impact of new state creation on the interests of other ethnic groups and the Federation as a whole. Of course, even as they pursue their legitimate self-interest, the commitment of NNPs of Ethiopia for the well-being of other NNPs and the Federation's proclaimed goal of building one 'political community' as stated in the preamble of the Constitution can be assumed. However, by putting all the trust on the democratic process within the NNP demanding statehood, the Constitutional procedure fails to put a mechanism in place that prevents state creating endeavors from adversely affecting other NNPs or the smooth functioning of the Federation as a whole.

Agitations for creation of new states are also likely to trigger other similar quests. The situation created in the SNNPR following the Sidama quest for regional statehood affirmed the demonstration effect of these demands. The extent to which the federal system and its institutions can absorb shocks emanating from demands for the strict application of the constitutional provisions in this area indeed leaves us with many uncertainties.

This issue is very likely to continue to be a source of an endogenous shock that may undermine the healthy functioning of the federal system. One solution could be amending the ethnic-centered nature of the process for the creation of new regional states by giving the federal legislative organs a substantive role in the process as it is the case in several federations. That however requires going through the lengthy and cumbersome constitutional amendment procedure. Due to the nature of the issue, such an amendment does not also appear possible without changing the general ethnic-centered orientation of the FDRE Constitution. On top of this, if new regional states are created by following the procedure under Article 47, the amendment procedure can practically become more rigorous than it is now. Therefore, if the system has to change, negotiations for amendment have to be done before the ethnic-centered procedure under Article 47 ends up in producing numerous new regions thereby making the amendment of not only this provision but also other provisions of the Constitution even more difficult. 